\title{
Aviation Medicine and the Army
}

Maj P Vyrnwy-Jones,

MB, BS, Dip Av Med, MSc, AFOM, RAMC

RAF Institute of Aviation Medicine, Farnborough

Maj R Thornton, MB, ChB, Dip Av Med, AFOM, MRAeS, RAMC

Royal Army Medical College, Millbank

SUMMARY: The purpose of this short series of articles is not to present the reader with a vast amount of technical data? soon to be forgotten, but to provide some items of general interest from the past, present, and future of Army aviation 3 Obviously there will be a concentration on medical matters, but the aim is to give the reader a feel for the rapid progress? being made in helicopter design and the likely problems we may face in the future.

The first article serves as an introduction to the series and three further articles will cover various aspects of the speciality. The second will be concerned with AAC helicopter accidents and will include accident investigation, crashworthiness ande the contribution made by pilot error. The third article will cover major environmental problems of helicopters, particulag⿴囗十오 noise, vibration and thermal stress. The fourth article will examine ways in which microprocessors and modern technolofigy will af fect future helicopter and ancillary equipment development; for instance, a helicopter with no external windows hres_

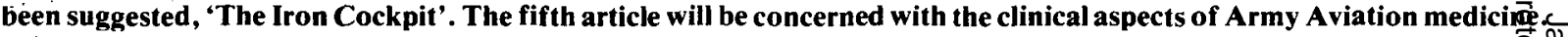

\section{Mythical Introduction}

The beginnings of aeronautical history in this country open with the legend of the attempt to fly by Bladud, the mythical king of Britain (Fig. 1). This first trial at winged

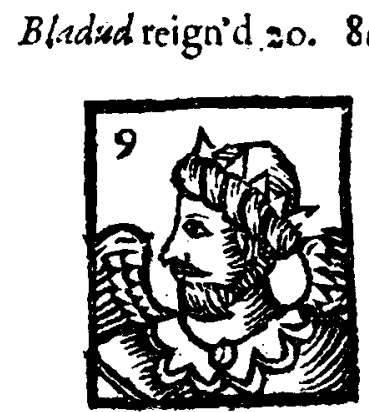

$\mathrm{B}$ Athe was by Bladidid to perfection brougint, By Necromanticke Arts, to flye he fought: As from: Towre he thought to cale thes shy He brake his necke, becaufe he foar'd too kight.

Fig. 1 Bladud the Flying King of Britain.

From Taylor's Memorial of English Monarchs 1622.

flight ended in Bladud's demise in $852 \mathrm{BC}$. The story was first recorded by Geoffrey of Monmouth (1100-1154) in his Historia Regum Brittaniae (1147). The legend relates how Bladud, the founder of the City of Bath and father of the better known, but equally mythical, King Lear knowlegeable in the arts of necromancy and taught ghछo subject widely throughout his kingdom. In an endeav to further his reputation, he designed an ornithopter (wi of feathers) for his first flight, which alas, was also 耳is terminal event, as he crashed into the temple of Apollo it Trinovantum (London).

\section{Early Army A viation}

The Army cannot claim an association with aviation that dates back to the early kings of Britain, but it did at least provide the location for one of the first aerial ascents in this country. This was made by the Italian, Vincent Lunardi who became the first aerial voyager in England, when he successfully rose in his balloon from the parade ground o the Army's oldest regiment, the Honourable Artillery Company, at City Road, London (Fig. 2), on the 15 Sep\& 1764.

These early pioneering flights were great publie occasions, and this first British one was attended by the Prince of Wales, Pitt, Fox, Burke, Lord North and man£ other distinguished personages of the day, including the accomplished and beautiful Duchess of Devonshire? Lunardi went on to make numerous further balloon ascent $\$$ and was often treated as a saint descending from heaven b. the incredulous peasantry. He became a great celebrity feted by European royalty and died a wealthy man on $3 P$ July, 1806 in London.

The Army approached aviation with great caution and the first military ballooning trials were carried out ap । Woolwich Arsenal in the balloon Pioneer, which first 

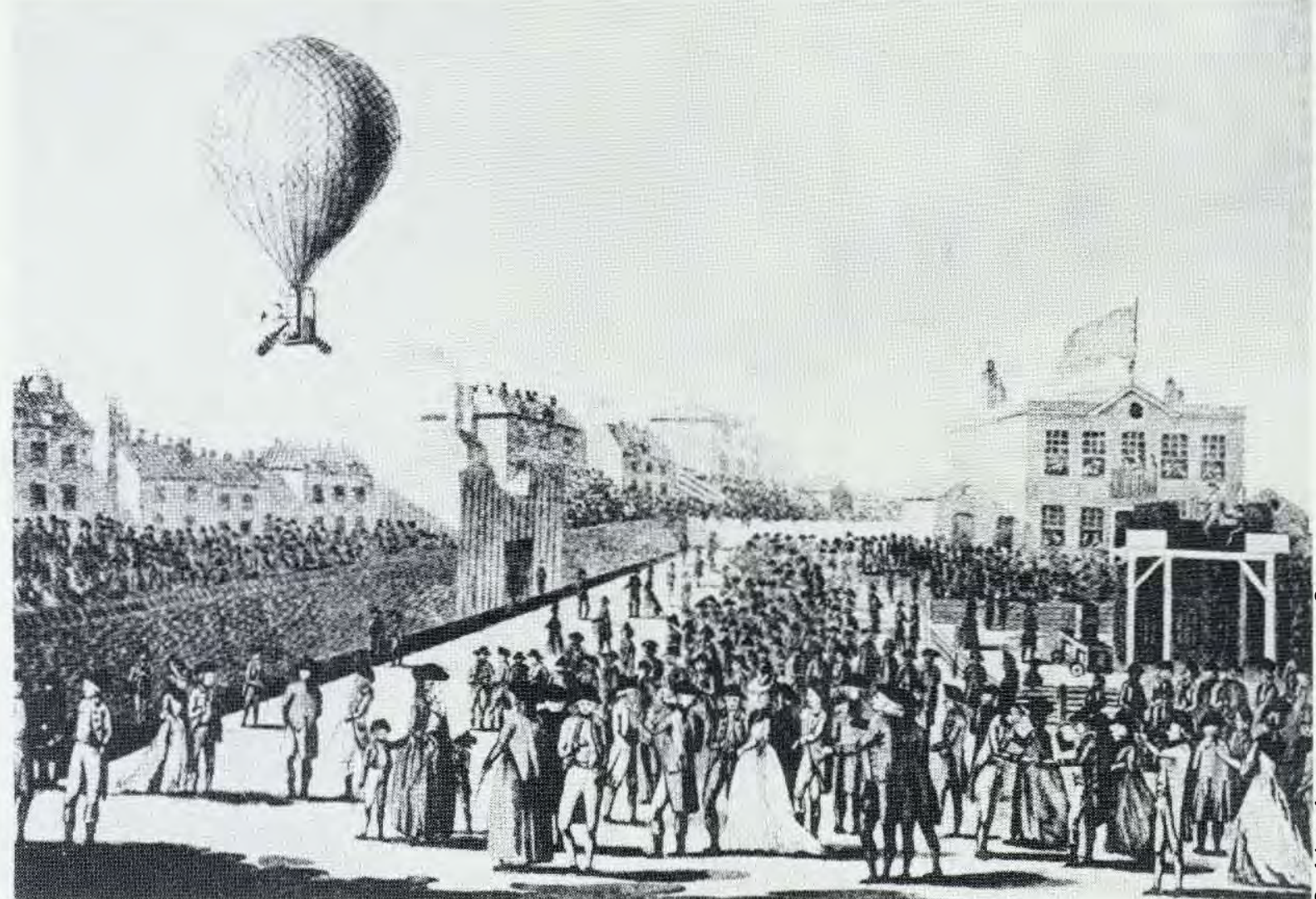

Fig. 2. The First Aerial Voyage in England.

Lunardi at the Artillery Parade Ground, Moorfields, 15 September, 1784.

ascended on 23 August 1878. Observation balloons were despatched to Bechuanaland in 1884 and to South Africa for the Boer War in 1899, and increased interest led to the Army's first airship, Nulli Secundus, being launched in 1907. Further developments were hastened by the rapid progress of aviation at home and abroad and the first Air Battalion was founded by the Royal Engineers in 1911. The battalion was raised to the status of a Corps on 13 April 1912. Thus began the heyday of Army aviation.

In September 1914 the Royal Flying Corps (RFC) represented only $0.5 \%$ of the British Expeditionary Force, but by means of a vast training programme the RFC expanded more than any other arm in the Army. On the 1st March 1918, the RFC consisted of 18,286 officers and 125,792 men. The RFC was hence larger than the Cavalry, Tank and Medical Corps. Casualties in the British air services, 1914-1918, were heavy, consisting of 4,579 officers and 1,567 men killed and thousands more missing, interned or wounded. The most costly period was 'Bloody April' of 1917 when the RFC lost 316 officers and men in France, representing one casualty per 92 flying hours. On April
Fools' Day 1918 the RFC and the Royal Naval Air Service were amalgamated to form the Royal Air Force.

\section{8 to the Present Day}

In 1942 official Army participation resumed with the formation of the first 5 RAF Air Observation Post (AOP) Squadrons. These were piloted by RA personnel whilst the RAF provided most of the technical support and aircraft. These Auster Mk. Is, soon followed by Mk IIIs, operated in all theatres, primarily directing artillery fire, and six pilots were killed by direct hits from allied shells. Other uses were reconnaissance, photography, communications, aerial cable laying and casevac.

In February 1942 the Army Air Corps was formed, originally consisting of a Glider Pilot Regiment. Corporal was the minimum rank with flying pay at two shillings a day. Later the Corps was joined by the Parachute Regt on its formation in August 1942, and by the SAS Regt in 1944. Glider pilots must have been men of remarkable resources. They often assembled the crated aircraft, flew them on to the objective and then fought with the ground troops on 
arrival. During Operation Market Garden 698 gliders were used in an attempt to take the Rhine Bridge at Arnhem. Tragically 229 glider pilots were killed during the course of this operation and indeed the Glider Pilot Regiment suffered the highest loss rate of any unit during World War II. The greatest and most successful airborne operation took place during Operation Varsity on 24 March 1945 , when 444 British and 906 American gliders were used to take bridges over the River Issel to prevent German counterattacks on the British 2nd Army. Four hundred and sixteen British gliders reached their destination, though 328 had been struck by ground fire. After the War most of the AOP and Glider Units were disbanded and Army Aviation began its post-war expansion on 1st September 1957 when the present Army Air Corps was founded. These years have seen the rapid development of the helicopter, which will be discussed later.

\section{Aviation Medicine}

Aviation medicine has its origins entwined with those of the history of flight itself, and hence its initial practice was concerned with of fsetting the ef fects of cold and hypoxia on the early balloonists.

The first accounts of altitude were made in 1800 by Robertson and Gay-Lussac. On an ascent to 23,000 feet Lussac complained of cold, benumbed fingers, laboured breathing, quickened pulse, parched throat, and a headache. In 1875 the first deaths attributed to hypoxia occurred, when H T Sivel and J E Croce-Spinelli lost their lives during an ascent to 27,950 feet. Their surviving companion, Gaston Tissandier, wrote at 25,000 feet, "I feel stupified and frozen, Croce-Spinelli is motionless in front of me; the mind and body weakens by degrees and imperceptibly without consciousness of it; no suffering is then experienced, on the contrary an inner joy". They had all been provided with oxygen bags but had not heeded the advice of the famous French physiologist, Paul Bert, who had warned them to use the oxygen before attaining too great a height. They had even experienced hypoxia in Bert's decompression chamber.

It was not until 1878 that Bert's monograph 'La pression barometrique' demonstrated that the effects of hypoxia were due to the diminished partial pressure of oxygen, associated with a reduced barometric pressure.

The involvement of the Royal Army Medical Corps with aviation began in 1911 when Capt E G R Lithgow (Fig. 3) was posted to the new Central Flying School (CFS) at Upavon on Salisbury Plain. He was the first medical man in this country to learn to fly. Lithgow obtained his Royal Aero Club aviators certificate, No 414, on 4th February 1913 at Upavon on a Short biplane. He went on to become a member of the first Medical Board to deal with the selection of flying officers and the invaliding and rehabilitation of injured or incapacitated aviators. To give the Senior Service its due, at the same time a Staff Surgeon $\mathrm{H} V$ Wells was attached to the Naval Wing of the CFS and he also got his aviators certificate on 24 May 1913. These two pioneers were Britain's first 'Flying Doctors',

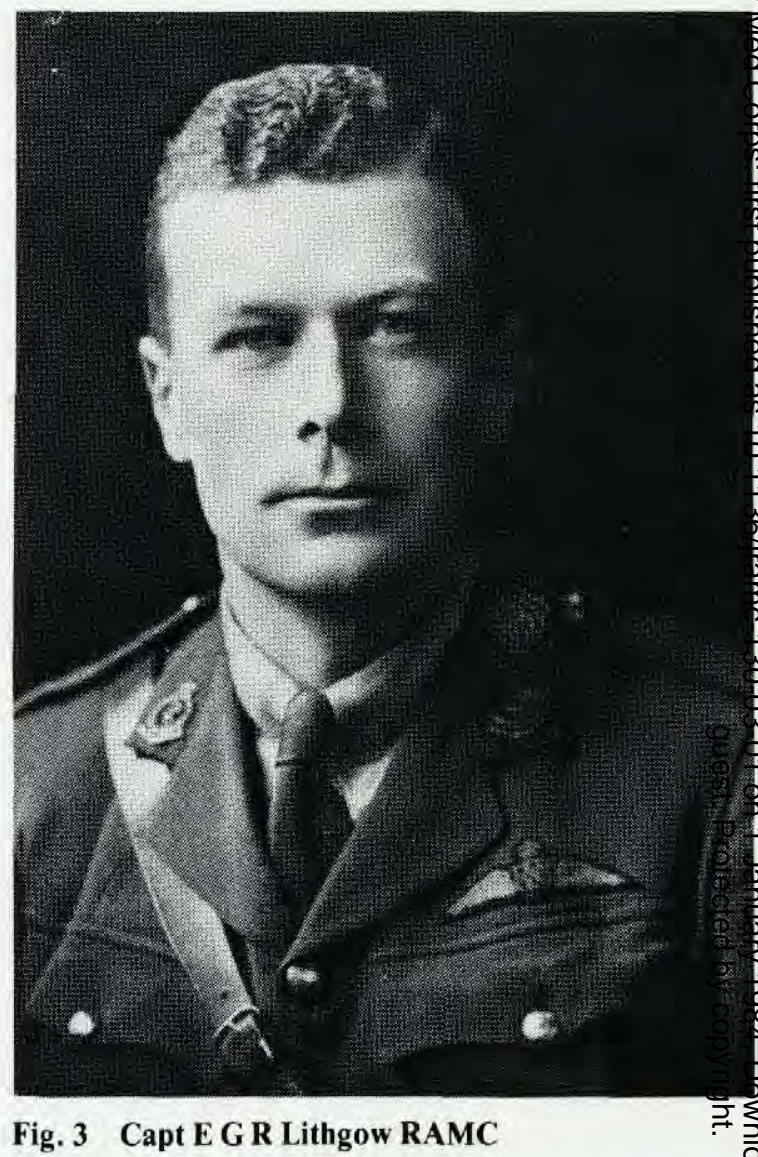

Fig. 3 Capt E G R Lithgow RAMC

The first medical treatise of flying to appear in the Britis press was J E Alder's 'Notes in the Medical Aspect o을 Aviation' in Hamel and Turner's book 'Flying'. Emphasi ̧̧ was laid on the importance of the medical examination to the would-be aviator, though he concentrated on the physiology of altitude rather than that of flying. He wrongly ascribed air sickness to the lack of oxygen. $\mathrm{H}$ Wells published two papers in the Journal of the Roya Navy Medical Services in 1915 and 1916 on accidents an flight safety with interesting comments on the recently introduced seat belts and flying helmets.

The first source of formal authority in British Aviatio Medicine was established in 1917 as the Special RFO Medical Board, chaired by a senior RAMC officer. There was an urgent requirement for some form of scientifig selection procedure and because of this Martin Flack wa? commissioned into the RAMC from his position on the Medical Research Committee (as the MRC was the known). He developed a series of tests, known as 'Thö Flack Tests', to assess the respiratory response of potential aviators. They consisted of measuring vital capacity, breathu holding capacity, expiratory force and the ability to sustaing a $40 \mathrm{~mm}$ column of mercury by blowing down a U-tube for 
as long as possible. In the breath holding test, the seated candidate was told to expire once fully, then to inspire and hold his breath as long as possible. Good pilots were expected to hold their breath for 60 secs and had to reach 45 secs to qualify for selection.

After the formation of the RAF in 1918, it was recognised, despite opposition from the medical heirarchy in the Army and Navy, that aviation presented new physiological and pathological problems which required special study and the training of aviation specialists! Major General Sir Matthew Fell became the first Director of the RAF's Medical Services with the acting rank of Air Commodore. He went on to become the Director General of the Army Medical Services, a unique achievement.

An article in the Lancet in 1918 by Capt T S Rippon, RAMC and Lieutenant E G Mannel dramatically illustrates the prevailing attitude to aviation then held. The aviator is described as possessing resolution, initiative, presence of mind, a sense of humour and judgement, he was alert, cheerful, optimistic, happy-go-lucky, generally a good fellow, and frequently lacking in imagination. The aviator was almost always a sportsman, and it was considered necessary for the well-being of the average pilot that he should indulge in a really riotous evening at least once or twice a month. The authors (not the current authors!) presumably had first hand experience of the latter. Rippon was a pilot of some 600 hours experience, a no mean achievement at the time.

Of all the medical of ficers attached to the RFC during the War, the contribution of Lt Col J L Birley was particularly significant. He studied the medical, psychological and physiological problems besetting the wartime aviator, particularly those of fatigue and mental illness induced by stress. He also made important contributions to the investigation of disorientation in flight.

The ending of the First World War saw the impetus for further advances in aviation medicine decline, with the sole effort coming from the RAF Physiological Laboratory at Mount Vernon Hospital. It was not until the 1930s when the RAFs policy to pursue altitude, speed and distance flying records, particularly the Schneider Trophy, stimulated further advances in protection from hypoxia, cold and the effects of acceleration.

In 1939 a Flying Personnel Research Committee was set up to advise the Secretary of State for Air on 'all matters concerning personnel which might affect safety and efficiency in flying'. The war years saw rapid progress being made in many important areas, including oxygen systems, $G$ protection, aptitude testing, vision, fatigue and accident investigation. Many of these research tasks continue today.

The Physiological Laboratory had transferred to a site at the Royal Aircraft Establishment, Farnborough, in 1939, but in 1945 it was renamed the RAF Institute of Aviation Medicine and moved to its existing location. On this site all the hardware of aviation medicine has been gathered, including the centrifuge, decompression chambers, deceleration track and climatic chambers, for investigating, by simulation, the stresses of flight. The Institute has always had its own complement of aircraft, flown by medical officer pilots, though now sadly reduced to one Hunter. The unique nature of the facilities and expertise available at the Institute has resulted in work being undertaken on aviation matters of concern not only to the RAF, but to the Royal Navy, Army and Civil Aviation Authority, many universities and industry, both here and abroad. The staff of the Institute includes over 20 doctors, mostly RAF and civilian, as well as one Naval and one Army aviation medicine senior specialist. The Army's resident involvement at the Institute is a recent one, dating from 1981.

There has been a department of aviation medicine at the Army Air Corps Centre, Middle Wallop, since 1958. It is now staffed by a consultant adviser and a trainee in aviation medicine. Senior specialists and specialists are located in BAOR at Detmold, and in the UK at Netheravon. Aviation medicine is now part of ACOM and the training includes completion of the Army Flying Course, the Diploma in Aviation Medicine, attendance at JDSC and later the MSc in Occupational Medicine at the London School of Hygiene and Tropical Medicine. The specialists advise the AAC op all matters of medical concern, including medicato standards, selection procedures and the general health o $\overline{0}$ the AAC's personnel. They are also actively engaged i research into areas such as noise, vibration, NBC protectio and development of new items of aircrew equipment, fo example, load carrying jerkins, body armour, helmets and $\vec{\varphi}$ aircrew respirators.

\section{Development of the Helicopter}

The first free flight of a true helicopter was made by Paul Cornu at Coquanvilliers near Lisieux, on 13 th November 1907. Development of these early helicopters was, however, slow and hampered by major technical problems, especiaily the difficulty of controlling such an inherently unstable machine. Interest remained firmly centred on fixed wing aircraft and later the autogyro. It was not until the midthirties and the war years that helicopters began to reappear as serious contenders to their more conventional counterparts.

Helicopters have become one of the most versatile and complex machines designed by man. They operate in nearly all the countries of the world and have become an accepted part of our lives. We are all familiar with their use in civil aviation, North Sea oil, industry, and their essential contribution to the recent conflict in the South Atlantic, and prior to that the Korean and Vietnam Wars. The latter was known as 'The Helicopter War' and it is salutory to remember that, during the period from 1961 onwards, the US Army lost 3,850 helicopters due to enemy action, accidents or operational reasons in South East Asia.

The number of helicopters in the military world is now quite staggering. The US Army alone can deploy over 10,000 rotorcraft and the Soviet Union has almost 5,000 available to its land forces. Sizes range from small two 


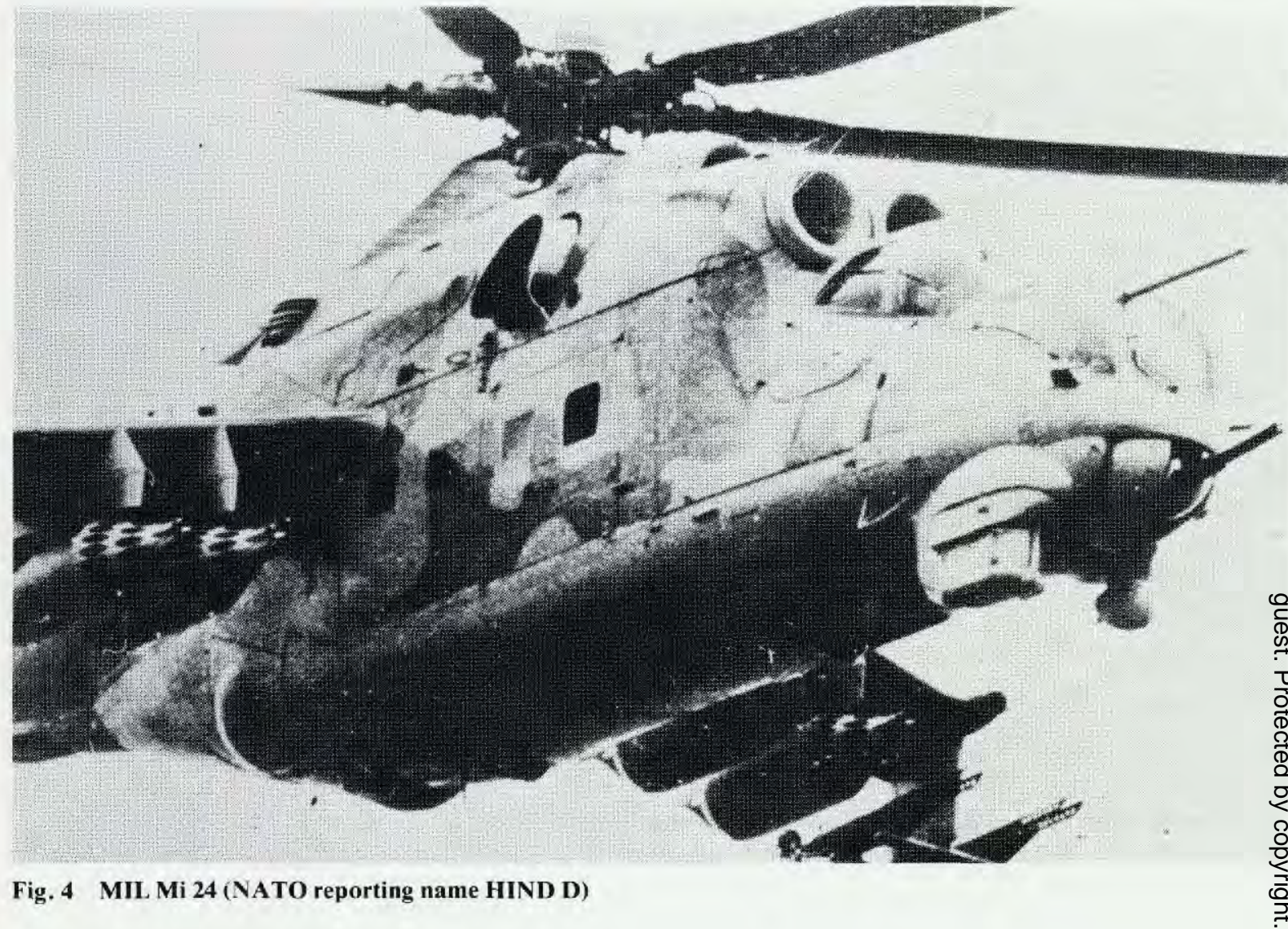

seaters to the giant Soviet Homer, which is capable of lifting a 40 ton payload. One of the most fearsome beasts in the modern battlefield is the dedicated attack helicopter, as exemplified by the Soviet Hind D (Fig. 4) and American Hughes AH64 Apache (Fig. 5). The Hind D is regarded not only as an anti-tank weapon but as a nap-of-the-earth tank, capaple of destroying opposing helicopters in flight. Reports in the Red Star claim they have proven superior to other forms of anti-tank weapons in terms of field view, manoeuvrability and fire power. Claims of up to a 19:1 exchange ratio have been made for this helicopter. Steel and titanium armour cover vital areas and the rotor blades are highly resistant to small arms fire. The windscreens are bullet proof. It can carry a range of anti-tank missiles and is equipped with a four-barrelled $12.7 \mathrm{~mm}$ machine gun and low light sensors.
The US Army's Apache is the very latest attack helicopter, which is due to supplement the Army's Cobras $\frac{\bar{\phi}}{\overrightarrow{0}}$ It too carries a range of missiles and a $30 \mathrm{~mm}$ chaingun for troop suppression. The nose houses a pilot night vision? sensor and a target acquisition/designation sight which comprises a forward looking infrared (for use during low. light levels), direct view optics, television and a laser range finder and target designator. Output from these can be fed to both crew members, either on a VDU or to an integratects helmet display system. The Apache is known as the 'Californian Armour Disposal System'.

Both helicopters and aviation medicine have come a long way, and in the next few articles we hope to demonstrate to the reader areas of medical importance in current ${ }_{0}^{\omega}$ helicopters and likely developments for the future. 


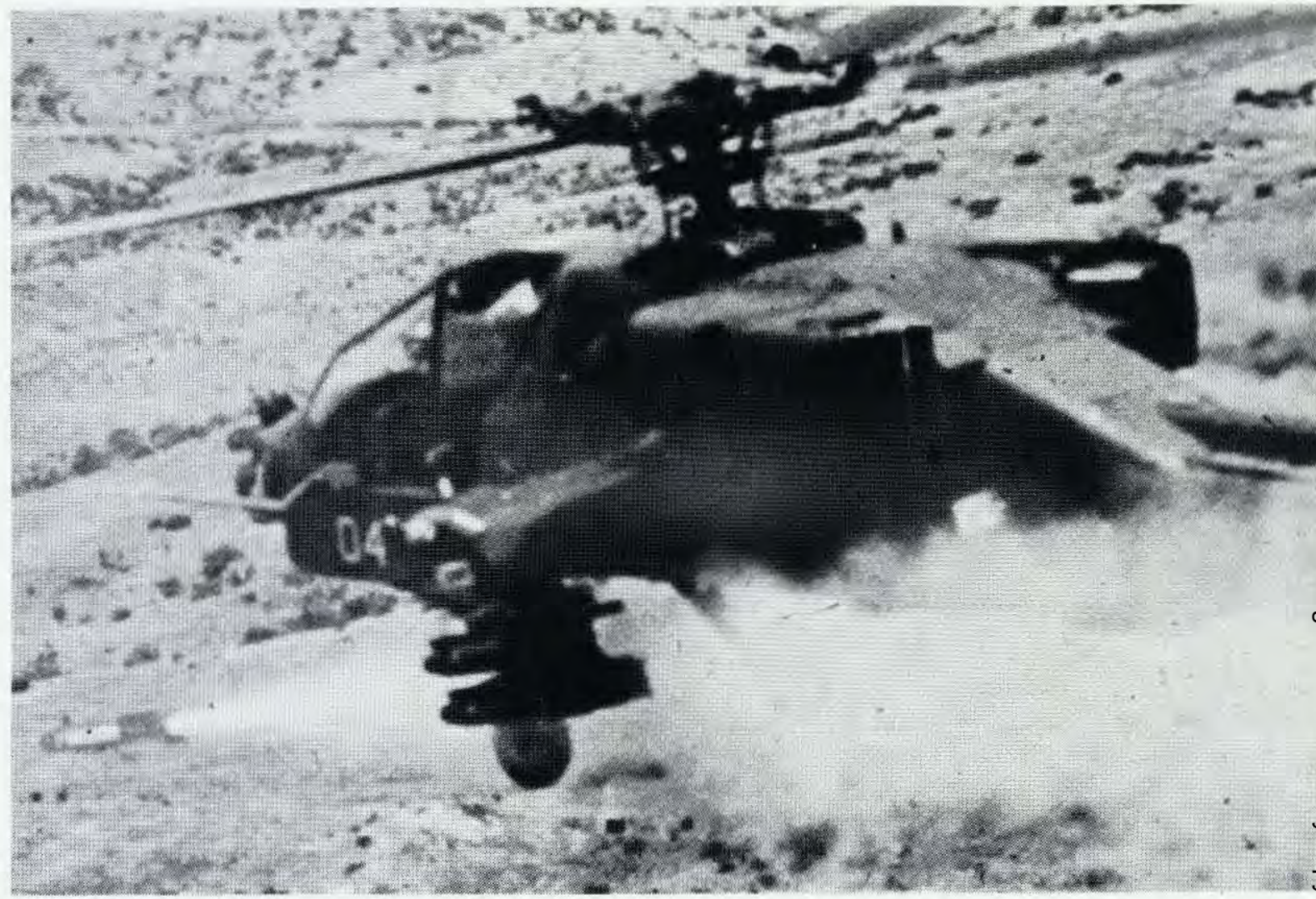

Fig. 5 The Hughes AH-64A Apache

MILITARY MEDICINE

Readers may wish to be reminded of this sister Journal (of the Association of Military Surgeons of the United States). The British member of the Editorial Board is appropriately our own Surgeon General (Designate), The Journal encompasses not only military but clinical topics. The Editor of the Journal of the Royal Army Medical Corps is of fering a prize to anyone who correctly diagnoses the test case for Diagnosis in the July 1984 issue. 